\title{
Studies on Leaching of Botrytis cinerea Conidia and Dye Absorption by Bacteria in Relation to Competition for Nutrients on Leaves
}

\author{
By A. SZTEJNBER G* AND J. P. BLAKEMAN \\ Department of Botany, University of Aberdeen, Aberdeen, $A B 92 U D$
}

(Received 6 November 1972; revised 21 February 1973)

\section{SUMMAR Y}

Botrytis cinerea conidia failed to germinate whilst being leached with water or mineral solution. Only a small proportion of conidia germinated in water after cessation of leaching but a high proportion germinated in the presence of glucose or mineral/glucose solutions. Sometimes minerals alone could restore germination of leached conidia. Conidia germinated well on membranes during leaching with glucose or mineral/glucose solutions.

The majority of isolates of bacteria obtained from leaves were positive or strongly positive in aniline blue dye-absorption tests, indicating the presence of extracellular polysaccharide. Uptake of nutrients into the polysaccharide sheath of bacteria situated near conidia may increase the concentration gradient from within to outside the conidium, so resulting in nutrient depletion and loss of germinability. The effect brought about by leaching of conidia was thought to simulate the action of bacteria. Similarities with spores inhibited in soil by fungistasis are discussed.

\section{INTRODUCTION}

Germination of Botrytis cinerea conidia was shown to be inhibited by bacteria on leaves of chrysanthemum (Blakeman \& Fraser, 197I) and garden or red beetroot (Blakeman, 1972). In neither investigation was the mechanism of inhibition determined. Germination was stimulated by a cell-free filtrate obtained from spore-containing droplets which had been placed on leaves. Before filtration, the droplets, either on the leaf or during tests in vitro after their removal from leaves, strongly inhibited germination. It was postulated that if an inhibitor was involved it must either be chemically unstable, or a volatile substance which disappeared so rapidly from filtrates as to have no detectable effect on germination of conidia. Later experiments (J. P. Blakeman, unpublished) failed to demonstrate the presence of such a volatile inhibitor.

Competition for nutrients between bacteria and fungal conidia is an alternative hypothesis to explain inhibition of conidial germination on leaf surfaces. Although Botrytis cinerea conidia germinate satisfactorily in distilled water, experiments reported below support this hypothesis and resemble studies on fungistasis in soils by Lingappa \& Lockwood (1964) and Ko \& Lockwood (I967).

\section{METHODS}

Conidia were collected from cultures of Botrytis cinerea and washed as previously described (Blakeman \& Fraser, I971). Bacteria were isolated from water droplets placed on leaves of garden or red beetroot (Beta vulgaris L., cultivar Detroit Globe) by removal of the droplets by pipette, transferring them to sterile Petri dishes, and pouring nutrient agar over them.

\footnotetext{
* Present address: Hebrew University of Jerusalem, Rehovot, Israel.
} 
Leaching of conidia. Botrytis cinerea conidia were placed (as $0.15 \mathrm{ml}$ of suspension containing 30000 conidia) between two $2.0 \mathrm{~cm}$ diam. filter membranes (Sartorius, pore size $0.6 \mu \mathrm{m}$ ) on a sintered-glass filter base mounted on a holder. Droplets were passed from a ground glass tap at the base of a reservoir on to the membranes at the rate of $10 / \mathrm{min}$. A slight vacuum was applied to the receiver flask which held the filter to ensure that droplets passed over the conidia and did not run off the membrane laterally and pass through uncovered portions of sintered glass. The apparatus used is illustrated in Fig. I. Droplets

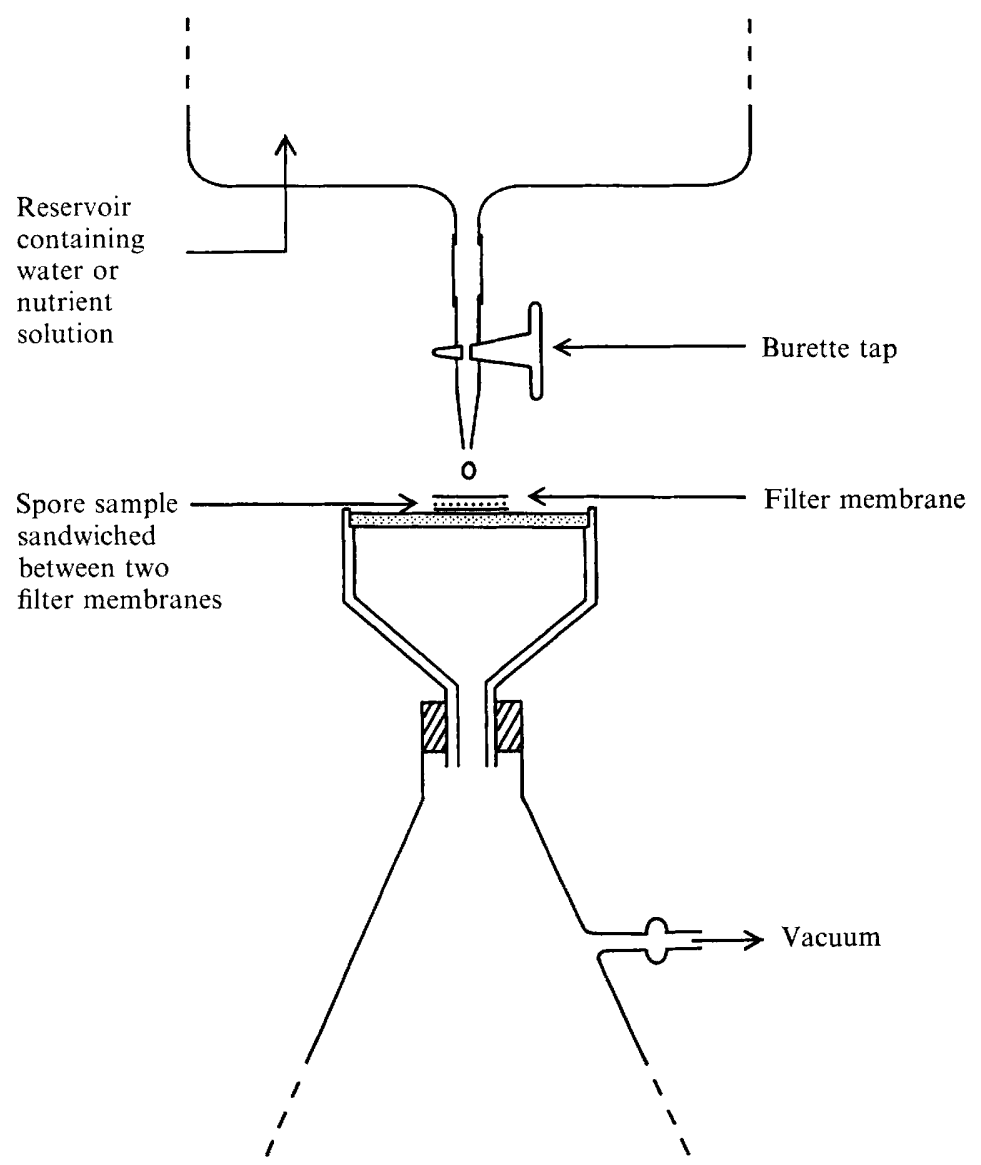

Fig. I. Diagram of apparatus used for leaching spores (not drawn to scale).

of water or nutrient solutions were passed over conidia for 24 or $48 \mathrm{~h}$. A volume of approximately $\mathrm{I} 600 \mathrm{ml}$ was collected in the receiver flask after $24 \mathrm{~h}$. The following nutrient solutions were used separately at a range of concentrations: glucose solution $(\mathrm{G})$, and mineral salts solution (Pfeffer), comprising: $\mathrm{Ca}\left(\mathrm{NO}_{3}\right)_{2}, 0.8 \mathrm{~g} ; \mathrm{MgSO}_{4}, 0.2 \mathrm{~g} ; \mathrm{KNO}_{3}, 0.2 \mathrm{~g} ; \mathrm{KCl}$, o. I g; $\mathrm{K}_{2} \mathrm{HPO}_{4}, 0.2 \mathrm{~g}$; trace element supplement; made up to I 1 with deionized water. The latter solution is described as $\mathrm{S}$, and dilutions of it as $\mathrm{S} / \mathrm{IO}, \mathrm{S} / \mathrm{IO0}$, etc. Mineral salts-glucose solutions contained $\mathrm{ro} \mathrm{g}$ glucose in addition, before dilution.

To provide controls of unleached conidia or to test viability after leaching, conidia were germinated under static conditions for $24 \mathrm{~h}$ between filter membranes moistened with $0.25 \mathrm{ml}$ of water or appropriate nutrient solution and enclosed in a Petri dish moist chamber. 
Table I. Effects of leaching with different concentrations of mineral/glucose solution on the germination of Botrytis cinerea conidia during $a 24 \mathrm{~h}$ period of treatment

\begin{tabular}{|c|c|c|c|c|c|}
\hline $\begin{array}{c}\text { Solution } \\
\text { used }\end{array}$ & $\begin{array}{c}\text { With }(+) \text { or } \\
\text { without }(-) \\
\text { leaching }\end{array}$ & $\underset{(\%)}{\text { Germination }}$ & $\begin{array}{l}\text { Mean length } \\
\text { of germ tubes } \\
(\mu \mathrm{m})\end{array}$ & $\begin{array}{c}\text { Mean no. } \\
\text { branches/germ } \\
\text { tube }\end{array}$ & $\begin{array}{c}\text { Mean length } \\
\text { of branches } \\
(\mu \mathrm{m})\end{array}$ \\
\hline Deionized & $\{-$ & 90 & $7 \mathrm{I}$ & 0 & 0 \\
\hline water & $\{+$ & 0 & 0 & 0 & 0 \\
\hline$S / 100$ & $\left\{\begin{array}{l}- \\
+\end{array}\right.$ & $\begin{array}{l}78 \\
98\end{array}$ & $\begin{array}{l}119 \\
150^{*}\end{array}$ & $\begin{array}{l}1-2 \\
I-3\end{array}$ & $\begin{array}{l}23 \\
16\end{array}$ \\
\hline $\mathrm{S} / 10$ & $\left\{\begin{array}{l}- \\
+\end{array}\right.$ & $\begin{array}{l}98 \\
98\end{array}$ & $\begin{array}{l}247 \\
347^{*}\end{array}$ & $\begin{array}{l}2-4 \\
2-4\end{array}$ & $\begin{array}{l}27 \\
22\end{array}$ \\
\hline $\mathrm{S}$ & $\left\{\begin{array}{l}- \\
+\end{array}\right.$ & $\begin{array}{r}99 \\
100\end{array}$ & $\begin{array}{l}391 \\
393\end{array}$ & $\begin{array}{l}2-5 \\
2-5\end{array}$ & $\begin{array}{l}38 \\
32\end{array}$ \\
\hline
\end{tabular}

$S$, standard concentration of mineral/glucose solution (see text).

* Differs significantly $(P=0.05)$ from its unleached counterpart.

Assessments of germination (from samples of at least 100 conidia) and of the length of the longest germ tube from each conidium (from samples of 50 germinated conidia), were made directly on membranes after staining with lactophenol cotton blue. Confidence limits $(P=0.05)$ for percentage germination of conidia were calculated by using the arcsine transformation (Sokal \& Rohlf, I969) and a $t$-test was applied to data for germ tube lengths.

Absorption of dye by bacteria. Paton's (1960) method was used to determine the rate of absorption of aniline blue by isolates of bacteria obtained from leaves of beetroot. Petri dishes of nutrient agar containing $5 \%$ sucrose were prepared. A channel of agar was removed approximately $\mathrm{I} \mathrm{cm}$ in width and running across the Petri dish so as to divide the agar into one-third and two-thirds portions. The channel was filled with the same medium incorporating $0.1 \%$ aniline blue. A spot inoculation of an isolate of a bacterium was made on the larger portion of agar about $8 \mathrm{~mm}$ from the channel and five further inoculations each at $8 \mathrm{~mm}$ centres further away from the channel. A blue coloration in the colony indicated the distance reached by the dye and was used as a measure of absorption by the bacterium after 2, 3 or 7 days. Two isolates of bacteria could be examined in this way on one agar plate. Isolates of bacteria used in this test were similar to those of Blakeman \& Sztejnberg (unpublished).

\section{RESULTS}

Leaching with deionized water decreased germination of Botrytis cinerea conidia from $90 \%$ in the unleached control to zero during a $24 \mathrm{~h}$ treatment period. On the other hand, leaching with mineral/glucose solutions had little or no harmful effect on the ability of conidia to germinate. Increasing the concentrations of mineral/glucose solutions progressively increased the extension growth and branching of developing germ tubes, leaching tending to increase the length of the main axis of the germ tube and to decrease the mean lengths of lateral branches (Table I).

Germination of Botrytis cinerea conidia was totally prevented by leaching with mineral salts alone while conidia in unleached controls germinated satisfactorily. After leaching with water only a small proportion of conidia could germinate under static conditions in water or dilute mineral solutions, but in stronger solutions (S/Io and S) the proportion of 
Table 2. Effects of mineral solution concentration on the germination of Botrytis cinerea conidia during and after a $24 h$ period of leaching

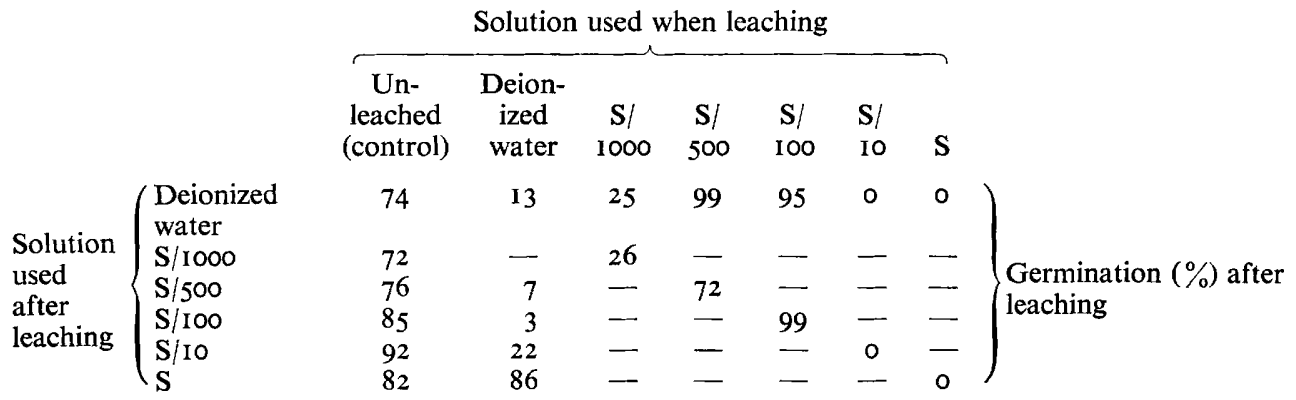

$\mathrm{S}$, standard concentration of mineral solution (see text).

-, not tested.

No germination occurred during leaching.

Table 3. Effects of glucose concentration on the germination of Botrytis cinerea conidia during and after $a 24 \mathrm{~h}$ period of leaching

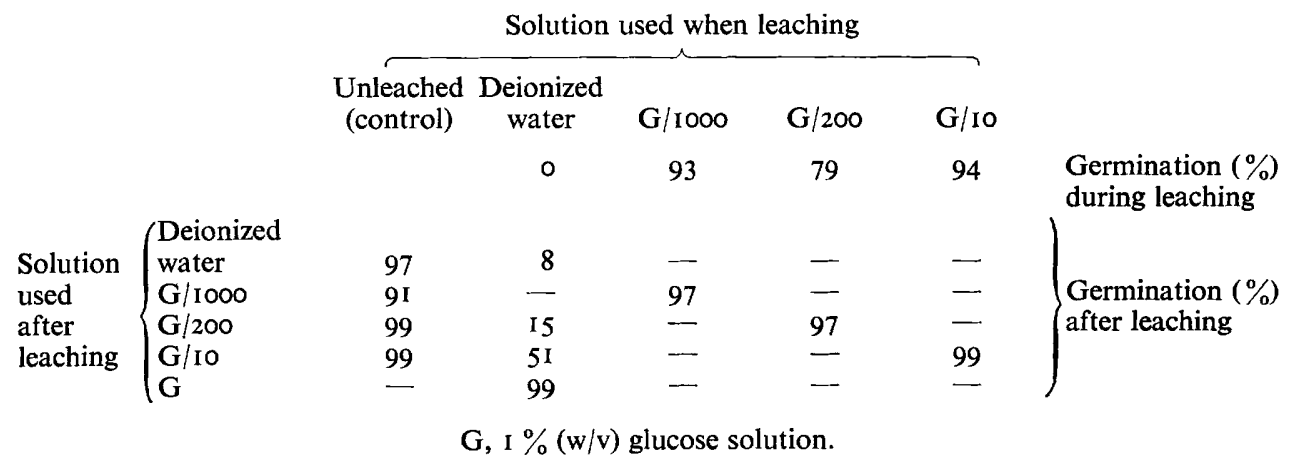

germinated conidia increased. After leaching with S/I000 only a small proportion of conidia could subsequently germinate in S/I000 under static conditions, but 72 to $99 \%$ of those leached in $\mathrm{S} / 500$ or $\mathrm{S} / 100$ subsequently germinated in $\mathrm{S} / 500, \mathrm{~S} / 100$ or water. Conidia leached in strong solutions ( $\mathrm{S} / \mathrm{IO}$ and $\mathrm{S}$ ) failed subsequently to germinate in either water, S/Io or S (Table 2).

With glucose solutions conidia germinated well both during leaching and after leaching in static conditions. The addition of glucose solutions to conidia previously leached with water resulted in an increase in the number germinated which was related to the strength of solution used. To achieve $50 \%$ or more germination a glucose concentration of $0.1 \%$ or higher was required (Table 3).

After a longer period of leaching conidia with water ( $48 \mathrm{~h}$ as opposed to $24 \mathrm{~h}$ ) fewer germinated under static conditions in water or in a dilute glucose solution ( $0.05 \%)$. However, leaching conidia for $48 \mathrm{~h}$ with water did not to any marked extent further impair germination in stronger glucose solutions ( $0 . \mathrm{I}$ or $\mathrm{I} .0 \%$ ) or in any concentration of mineral/glucose solution. The latter was in general more effective than glucose alone in restoring germinability to leached conidia (Table 4). 
Table 4. Effects of concentration of mineral/glucose, or of glucose alone, on germination of Botrytis cinerea conidia after a 24 or 48 h period of leaching with water

Germination $(\%)$

Duration (h) of leaching with water

ion used

after leaching

\begin{tabular}{|c|c|c|}
\hline & Duration & ith $\mathrm{x}$ \\
\hline & 24 & 48 \\
\hline (Deionized water & I 3 & 3 \\
\hline $\mathrm{G} / 200$ & I5 & 4 \\
\hline G/10 & $5 \mathrm{I}$ & 82 \\
\hline $\mathrm{G}$ & 99 & 71 \\
\hline$S_{/} / 1000$ & 5 & 22 \\
\hline $\mathrm{S} / 500$ & 55 & 53 \\
\hline $\mathrm{S} / 10$ & 89 & 72 \\
\hline S & 95 & 80 \\
\hline
\end{tabular}

G, $1 \%(w / v)$ glucose solution.

$\mathrm{S}$, standard concentration of mineral/glucose solution (see text).

Table 5. Absorption of aniline blue dye by colonies of bacteria and Sporobolomyces on agar plates

Figures are given for the min. mean, and max. absorption shown by isolates tested in any one group.

\begin{tabular}{|c|c|c|c|c|}
\hline \multirow[b]{2}{*}{ Isolates } & & \multicolumn{3}{|c|}{$\begin{array}{c}\text { Colony number reached by dye } \\
\text { Time (days) }\end{array}$} \\
\hline & & 2 & 3 & 7 \\
\hline Pseudomonas & $\left\{\begin{array}{l}\text { Min. } \\
\text { Mean* } \\
\text { Max. }\end{array}\right.$ & $\begin{array}{l}I \\
1 \cdot 5 \\
3\end{array}$ & $\begin{array}{l}I \\
2 \cdot 0 \\
5\end{array}$ & $\begin{array}{l}\text { I } \\
2 \cdot 6 \\
6\end{array}$ \\
\hline cio Isolates & $\left\{\begin{array}{l}\text { Min. } \\
\text { Mean } \dagger \\
\text { Max. }\end{array}\right.$ & $\begin{array}{l}I \\
1 \cdot 3 \\
2\end{array}$ & $\begin{array}{l}1 \\
I \cdot 6 \\
2\end{array}$ & $\begin{array}{l}\text { I } \\
2 \cdot 2 \\
4\end{array}$ \\
\hline Coryneforms & $\left\{\begin{array}{l}\text { Min. } \\
\text { Mean }+ \\
\text { Max. }\end{array}\right.$ & $\begin{array}{l}\text { I } \\
I \cdot 8 \\
2\end{array}$ & $\begin{array}{l}1 \\
2 \cdot 5 \\
3\end{array}$ & $\begin{array}{l}2 \\
3 \cdot I \\
4\end{array}$ \\
\hline Sporobolomyces & $\left\{\begin{array}{l}\text { Min. } \\
\text { Mean } \$ \\
\text { Max. }\end{array}\right.$ & $\begin{array}{l}I \\
I \cdot 2 \\
2\end{array}$ & $\begin{array}{l}1 \\
2 \cdot 0 \\
3\end{array}$ & $\begin{array}{l}3 \\
3 \cdot 8 \\
4\end{array}$ \\
\hline
\end{tabular}

* Based on 30 isolates, $\dagger$ based on $\mathrm{I} 2$ isolates, and $\ddagger$ based on four isolates.

\section{Absorption of dye}

A comparison of the pattern of absorption of aniline blue dye by colonies of a selection of isolates of bacteria and isolates of the pink yeast Sporobolomyces is shown in Table 5 . Not all isolates in any one group of bacteria responded similarly. Figures are therefore given for an isolate showing the least and for one showing the most dye absorption, together with a mean for all isolates tested in any one group. Isolates were considered to show a positive ability to absorb dye if it was detected in the second colony or beyond.

In some isolates of Pseudomonas dye was detected in the first colony only (nearest the source) after 7 days whilst in others dye had reached the sixth colony. Dye absorption in the majority of isolates was between this range. In the cro group of isolates (non-motile, yellowpigmented, oxidative Gram-negative rods) the range in absorption of dye between isolates varied from the first to the fourth colony after 7 days. There was a narrower range in dye 


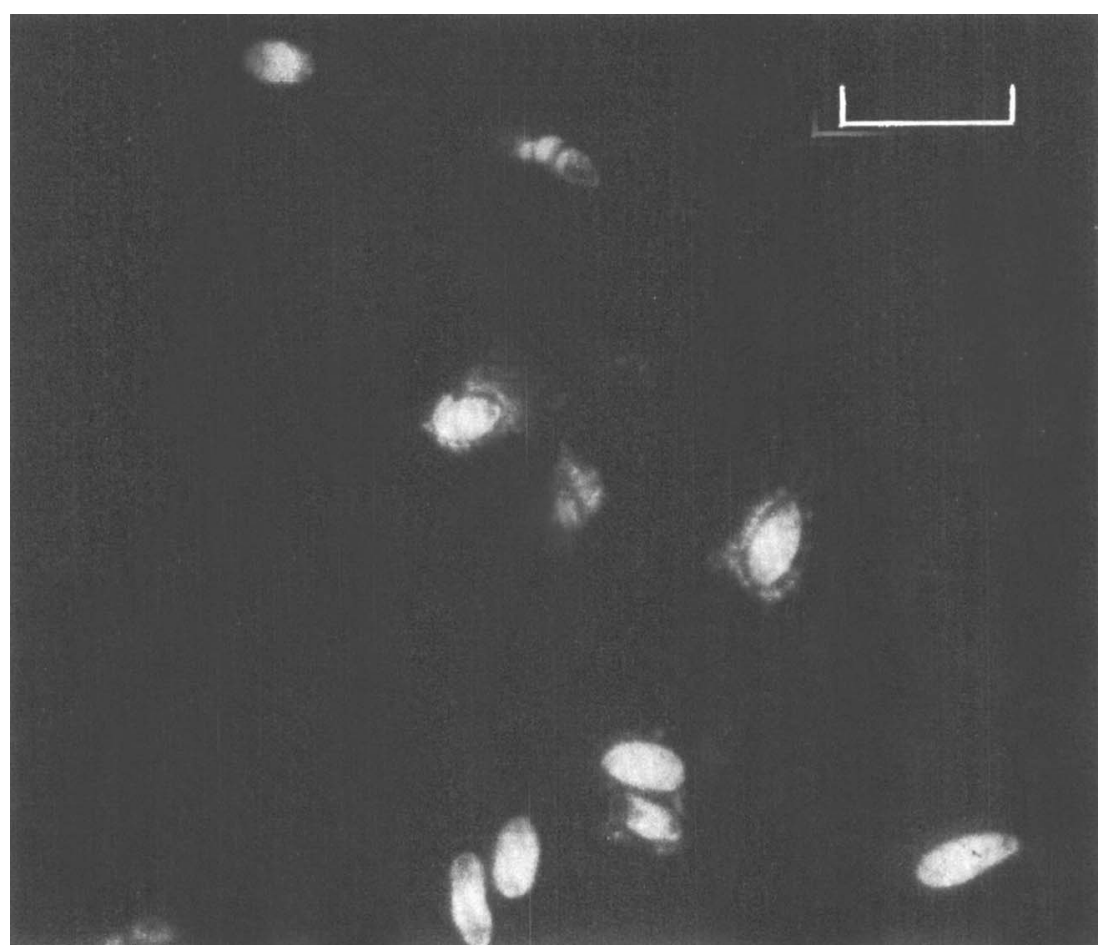

Fig. 2. Conidia of Botrytis cinerea surrounded by bacteria on a beetroot leaf, after staining with acridine orange. Conidia had been placed on the leaf in a water suspension $48 \mathrm{~h}$ earlier. Scale marker represents $20 \mu \mathrm{m}$.

absorption between isolates of coryneforms, dye generally reaching the third or fourth colony. A similar absorption pattern was shown by isolates of Sporobolomyces.

The presence of large numbers of bacteria surrounding Botrytis cinerea conidia $48 \mathrm{~h}$ after being placed on a beetroot leaf is shown in Fig. 2 by incident-light fluorescence after staining with acridine orange. Yeast cells were often present in infection droplets but not surrounding conidia. No lysis or damage to conidia by bacteria was seen.

\section{DISCUSSION}

The presence of large numbers of bacteria surrounding Botrytis cinerea conidia in droplets on beetroot leaves indicated that there may be a zone enriched by nutrients around the conidium. A steady leakage of nutrients occurred from $B$. cinerea conidia when placed in sterile water (Fraser, I97I) but germination was not impaired. Prevention of germination in droplets on leaves may have resulted from a continuous uptake of nutrients by bacteria leading to a steeper increase in concentration gradient from within to outside the conidium, i.e. a 'sink' effect. The experiments with $B$. cinerea conidia on filter membranes were an attempt to simulate by physical means the possible action of bacteria on conidia on plant surfaces. Continuous passage of water over conidia would create a sharp rise in concentration gradient which may have been the cause of the failure of $B$. cinerea conidia to germinate.

Prevention of germination of Botrytis cinerea conidia during leaching with water or mineral salt solutions may be because of exhaustion of endogenous nutrient reserves of the 
conidia, coupled with loss of soluble metabolites. As a small proportion of conidia germinated in water after leaching, exhaustion of nutrients did not occur in every conidium.

Mineral/glucose solutions or glucose alone could restore germinability after leaching with water. This suggested that loss of simple carbohydrates from conidia prevented germination. However, high concentrations of mineral salts solution alone could partly restore germinability to conidia leached by water. When conidia were leached with only low concentrations of mineral salts, they could subsequently germinate in static conditions in water or in similar concentrations of minerals. These observations suggest that loss of carbohydrate cannot entirely explain the failure of conidia to germinate and there may be a requirement for mineral salts to maintain an internal environment of suitable ionic strength. The loss of germinability of conidia in water or mineral salts solution after previous leaching with high concentrations (only) of mineral salts solution may be associated with osmotic action. The supply of nitrogen and mineral salts was evidently not exhausted from conidia by leaching with glucose solutions since good germination occurred under these conditions.

Amino acids are known to be lost from Botrytis cinerea conidia and to be partly responsible for the stimulation of multiplication of bacteria in droplets on leaves (Fraser, 197I). Depletion of amino acids and carbohydrates in solution in droplets on leaves was associated with a rise in numbers of bacteria (Fraser, I97I ; Blakeman, 1972). The results of the present work suggest that some loss of nitrogen compounds by leaching from $B$. cinerea conidia does not prevent germination if adequate soluble carbohydrates are present.

Experiments involving leaching of conidia with water on membranes paralleled those of Ko \& Lockwood (1967) who leached spores of a selection of soil fungi. They showed that spores which were sensitive to fungistasis in soil were unable to germinate on membranes during leaching with water. After prolonged periods of leaching spores were shown to be germinable if suspended in nutrient solutions. As a result of these studies Ko \& Lockwood concluded that it was not necessary to postulate the existence of fungistatic substances to explain the failure of fungal spores to germinate in soil.

Experiments on the absorption of dye by colonies of bacteria indicated that the majority of isolates obtained from leaves are positive or strongly positive in this respect. Paton (I960) showed that only colonies producing extracellular polysaccharide absorb the dye and suggested that the high incidence of this characteristic amongst pathogenic and saprophytic bacteria on plant surfaces was associated with their existence in an environment where nutrients were often in restricted supply. This is often true of the surfaces of plant leaves, e.g. on leaves of garden beetroot Io to $40 \mu \mathrm{g} / \mathrm{ml}$ of carbohydrate and 0.02 to $0.20 \mu \mathrm{mol} / \mathrm{ml}$ of amino acids are present (Blakeman, 1972). The formation of polysaccharide from simple sugars is known to create a concentration gradient which attracts solutes to the polymer.

Addition of Botrytis cinerea conidia to water droplets placed on leaves results in an initial increase in concentration of nutrients as a result of leakage from the conidia followed by a rise in numbers of bacteria and an inhibition of germination (Blakeman \& Fraser, I97I). A similar sequence has been shown to occur after the addition of fungal spores to soil and is claimed to be responsible for the fungistatic condition associated with most soils (Lingappa \& Lockwood, 1964).

Fungal spores in soil which are inhibited by fungistasis can be stimulated to germinate by addition of nutrients. Supplementation of droplets on leaves with nutrients, e.g. $1 \%$ glucose or mineral salts/glucose, overcame inhibition of germination of Botrytis cinerea conidia and stimulated growth of germ tubes despite the presence of large numbers of bacteria (Blakeman \& Fraser, 197I). It is assumed that under such conditions bacteria are unable to take up all the available nutrients and hence do not prevent germination of conidia. 
We thank Dr A. M. Paton for helpful advice and are indebted to Miss L. McPherson for technical assistance.

\section{REFERENCES}

Blakeman, J. P. (1972). Effect of plant age on inhibition of Botrytis cinerea spores by bacteria on beetroot leaves. Physiological Plant Pathology 2, 143-152.

Blakeman, J. P. \& Fraser, A. K. (I97I). Inhibition of Botrytis cinerea spores by bacteria on the surface of chrysanthemum leaves. Physiological Plant Pathology I, 45-54.

Fraser, A. K. (1971). Growth restriction of pathogenic fungi on the leaf surface. In Ecology of Leaf Surface Micro-organisms, pp. 529-535. Edited by T. F. Preece and C. H. Dickinson. London: Academic Press.

Ko, W. H. \& Lockwood, J. L. (I967). Soil fungistasis: relation to fungal spore nutrition. Phytopathology 57, 894-901.

LingapPa, B. T. \& Lockwood, J. L. (1964). Activation of soil microflora by fungus spores in relation to soil fungistasis. Journal of General Microbiology 35, 2 I 5-227.

Paton, A. M. (1960). The role of Pseudomonas in plant disease. Journal of Applied Bacteriology 23, 526-532.

SoKal, R. R. \& Rohlf, F. J. (1969). Biometry. San Francisco: W. H. Freeman. 